University at Albany, State University of New York

Scholars Archive

\title{
Motivating Political Participation Among Youth: An Analysis of Factors Related to Adolescents' Political Engagement
}

\author{
Brett Levy \\ University at Albany, State University of New York, bllevy@albany.edu \\ Thomas Akiva \\ University of Pittsburgh
}

Follow this and additional works at: https://scholarsarchive.library.albany.edu/etap_fac_scholar

Part of the Education Commons

\section{Recommended Citation}

Levy, Brett and Akiva, Thomas, "Motivating Political Participation Among Youth: An Analysis of Factors Related to Adolescents' Political Engagement" (2019). Educational Theory and Practice Faculty Scholarship. 31.

https://scholarsarchive.library.albany.edu/etap_fac_scholar/31

This Article is brought to you for free and open access by the Educational Theory and Practice at Scholars Archive. It has been accepted for inclusion in Educational Theory and Practice Faculty Scholarship by an authorized administrator of Scholars Archive. For more information, please contact scholarsarchive@albany.edu. 


\title{
Motivating Political Participation Among Youth:
}

\section{An Analysis of Factors Related to Adolescents' Political Engagement}

\author{
Brett L. M. Levy \\ University at Albany, State University of New York
}

Thomas Akiva

University of Pittsburgh

Citation Information for Published Version:

Levy, B. L. M. \& Akiva, T. (2019). Motivating political participation among youth; An analysis of factors related to adolescents' political engagement. Political Psychology, 40(5), 1039-55. DOI: $10.1111 /$ pops.12578

Acknowledgements:

The Spencer Foundation funded this research, and we greatly appreciate their support. We would also like to thank the study participants, who openly shared their perspectives with us. Correspondence concerning this article should be addressed to Brett L. M. Levy, University at Albany, State University of New York, Catskill 269, 1400 Washington Avenue, Albany, NY 12222. Email: bllevy@albany.edu 


\begin{abstract}
Prior research has identified political efficacy and political interest as strong predictors of political participation, but few studies have examined these two attitudes in tandem or compared their relative importance vis-à-vis political participation. Drawing on the expectancy-value model of motivation, we begin to address this research gap while also considering several related issues. Our sample includes a diverse group of high school students in grades 10,11, and $12(\mathrm{~N}=422)$ from the midwestern United States. Through quantitative analyses of participants' survey data, we found that political interest (a central aspect of value) and political efficacy (closely related to expectancy) predicted participants' expected future political participation, controlling for background characteristics-and that political interest was a particularly strong predictor. In addition, we identified political engagement differences on various demographic measures, such as grade level. We also found a significant interaction between political interest and internal political efficacy, suggesting that high levels of both attitudes can have an especially positive effect on adolescents' political participation. We discuss the implications of these findings for researchers and educators interested in fostering political engagement among youth.
\end{abstract}

KEY WORDS: civic learning, motivation, political engagement, political participation 
The purpose of this paper is to explore key attitudes related to motivating political participation among youth. In many democratic societies, engagement in political activities, such as voting, fluctuates significantly over time. During the second half of the twentieth century, voter turnout in several Western European countries, including Finland and Austria, fell by more than 10 percentage points (Franklin, 2004), and in the United States, voter turnout in presidential elections is below its peak from several decades ago (U.S. Elections Project, 2016). This limited political involvement, quite prevalent among young people (Bouza, 2014), often leaves certain individuals and groups represented by officials who are inattentive to their concerns (Bartels, 2008; Levine, 2007; Levinson, 2012).

To strengthen democratic engagement—and ultimately democracy itself, it is important to foster broad political engagement and to develop a better understanding of how to support such engagement. Adolescence can be a vital stage in life to shape individuals' long-term participatory habits (Chan, Ou, \& Reynolds, 2014; Jennings \& Stoker, 2004; McAdam, 1988), so examining how to strengthen political engagement among youth could provide valuable insights. There are many programs that aim to foster political engagement among youth—some more successful than others (Levy, Solomon, \& ColletGildard, 2016; Manning \& Edwards, 2014), so research into the attitudes that are most central for such development could help these programs achieve their goals.

Prior studies have identified political efficacy and political interest as strong predictors of political participation (Beaumont, 2010; Stromback \& Shehata, 2010). Building on this, researchers have begun to examine how to foster these attitudes, especially political efficacy (e.g., Hahn, 1998). However, few studies have examined political efficacy and political interest in tandem or compared their relative importance vis-à-vis 
political participation. Drawing on the expectancy-value model of motivation, this paper begins to address this research gap while also considering several related issues. Our findings provide insights about which attitudes are most important to foster and also identify notable political engagement differences among various demographic groups.

\section{Background}

To frame our study, we consider prior theory and research related to motivating adolescents' political engagement. First, we summarize the major tenets of the expectancyvalue theory of motivation and describe its relevance to political engagement. Next, we briefly review trends in the study of political efficacy and political interest, two attitudes that researchers have found to be closely related to political participation. Finally, we note demographic differences in political engagement that research has identified. In the process, we explain how the present study contributes to the existing literature on these issues.

\section{The Expectancy-Value Model of Motivation}

Drawing on theory and research from philosophy (e.g., James, 1890), natural science (e.g., Tolman, 1932), and social science (Rotter, 1954; Atkinson, 1964; Bandura, 1977), researchers in psychology and education have found considerable empirical evidence for the expectancy-value model of achievement motivation (Muenks, Wigfield, \& Eccles, 2018). The expectancy-value model posits that individuals are motivated to engage in tasks based on (1) expectations of success and (2) valuing those tasks (e.g., Eccles, 2005; Wigfield \& Eccles, 2000). Expectancies are determined by individuals' expectations that they can 
succeed on certain upcoming tasks, either in the immediate or distant future (Eccles et al., 1983). This concept, the perception of one's own competence, can be general or domainspecific and is closely related to Bandura's (1997) notion of self-efficacy, defined as “a judgment of one's ability to organize and execute given types of performances" (p. 21). The difference between self-efficacy (belief that one is able to accomplish something the set out to do) and expectancy (belief that one will accomplish something they set out to do) is theoretically small in the context of political involvement.

Value has several components, including intrinsic value, the enjoyment one gets from doing a particular task or set of tasks. Scholars have argued that interest is closely related to intrinsic value (e.g., Deci, Vallerand, Pelletier, \& Ryan, 1991). Studies have found that expectancies and values consistently predict achievement-related choices in academics, sports, and social activities (Mahoney, Vandell, Simpkins, \& Zarrett, 2009; Wigfield, Eccles, Mac Iver, Reuman, \& Midgley, 1991), and that expectancies and values are shaped by youths' goals, self-schemata (e.g., self-concept of ability), and affective memories (Wigfield \& Eccles, 2002).

There is substantial related research that has evolved in a separate domain, conducted mostly by political scientists. This work explores why individuals in democratic societies choose whether or not to participate in the political process (i.e. vote, contact representatives, join political organizations, etc.). Whereas early political science research found that political participation was related to certain demographic variables, such as age and educational background (e.g., Almond \& Verba, 1960; Campbell, Gurin, \& Miller, 1954), more recent research has examined the influence of social relations and personality characteristics. For example, in a study of West German young adults, Krampen (1991) 
found that situation-specific variables were stronger predictors of political involvement for political activists but that non-activists' involvement was better predicted by personality variables. Over the past dozen years, scholars have found political participation to be related to other social factors, such as political context (Geys, 2006), social trust (Kelly, 2009), social connectedness (Robnett, 2007; Simmons, 2014), and religiosity (Smetana \& Metzger, 2005). Most notably, studies have found that among the most reliable predictors of political participation are two psychological attitudes that are often related to some of these other variables: political efficacy (Becker, 2004; Campbell et al., 1954; Guyton, 1988; Hope \& Jagers, 2014) and political interest (Leighley \& Vedlitz, 1999; Stromback \& Shehata, 2010) - which are akin to the main elements of the expectancy-value model.

Political interest is commonly defined as "citizens' willingness to pay attention to politics at the expense of other endeavors" (Almond \& Verba, 1963; Lupia \& Philpot, 2005), and political efficacy is conceptualized as the extent to which individuals believe that their actions can influence the government (Beaumont, 2010; Campbell et al., 1954). Scholars of political engagement distinguish between internal political efficacy (IPE), one's sense of competence for understanding and acting in the political sphere (through writing and speaking, for example), and external political efficacy (EPE), the belief that the government or society will respond to one's actions (Levy, 2013; Balch, 1959; Miller, Miller, \& Schneider, 1980). The present study examines the degree of impact that political efficacy and interest have on adolescents' expected future political participation. 


\section{Studies of Political Efficacy and Political Interest}

Whereas researchers have examined nuances related to political efficacy's effects and development (e.g., Zukin, Keeter, Andolina, Jenkins, \& Delli Karpini, 2006), less research has been done on political interest. For example, Wolak (2018) recently explored how political efficacy varies based on local opportunities for political voice $(n=1500)$, finding evidence that certain policies in U.S states can strengthen residents' efficacy. Also, in an analysis of survey data from over 6,000 participants in the United States and Denmark, Rasmussen and Norgaard (2018) found that the socioeconomic context in which one lives can affect external, but not internal, political efficacy. In rural China, Pei and colleagues (2018) examined the impact of political efficacy on participation in public deliberations, finding positive effects of both internal and external political efficacy. In one unique study of adolescents in ten countries, Schultz (2005) found that the effects of political efficacy differed for younger and older students, explaining more of the variance in expected political activities for 14-year-olds than for upper secondary students. As political scientists have explored these broader trends, educational researchers have undertaken smaller-scale studies to examine how political efficacy develops in classrooms, noting the potential value of discussions (Morrell, 2005), civic action projects (Levy, 2011), and political simulations (Dressner, 1990; Levy, 2018; Stroupe \& Sabato, 2004).

Meanwhile, some studies suggest that it may be important for educational researchers to include political interest as a focal attitude in their studies. For example, Schultz (2005) found that political interest had a significant predictive effect on expected political activities - and that this attitude may influence political efficacy. Levy's (2013) mixed methods study of political efficacy also suggested that political interest may have a 
positive impact on political efficacy. Diemer and Rapa's (2016) research raises questions about researchers' focus on political efficacy over political interest. In their exploration of survey data from 2,811 U.S. ninth graders in the Civic Education Study, the researchers were surprised to find that political efficacy did not mediate or moderate the relationship between critical reflection and expected political action. These studies do not undermine the importance of political efficacy, but they do suggest that it is important to examine both political interest and political efficacy—and consider their relative effects on political participation.

However, few studies have examined these two attitudes in tandem or compared their relative importance vis-à-vis political participation. One exception is from Liem \& Chua (2013), whose study of Indonesian youth found that both expectancy and value beliefs mediated the relationship between background factors and society-oriented future goals-with value beliefs playing the larger role. Although these researchers did not specifically examine the extent to which the expectancy-value model related to adolescents' likelihood of participating in political action, their findings suggest that this is a worthwhile issue to explore. The present study explores this question.

\section{Demographic Differences in Political Engagement}

Furthermore, it is important to consider how demographic factors, such as race, age, and gender, may relate to political engagement. Although substantial research indicates that numerous developmental changes occur during the high school years (e.g., Mills, Lalonde, Clasen, Giedd, \& Blakemore, 2014; Shaffer \& Kipp, 2013), research on changes in political engagement during this period has been quite limited. Some researchers have 
found that an individual's political efficacy tends to make one wide arc, starting and ending relatively low and peaking during mid-to-late middle age (Campbell et al., 1954; Wu, 2003). On the other hand, Prior (2010) analyzed numerous datasets to conclude that political interest typically remains stable from early adulthood onward. One early study (Ehman, 1972) indicates that political efficacy remains stable between 10 th and 12 th grades, but researchers have found that adolescence is a vital time for the development of political identities and attitudes (e.g., Jennings \& Stoker, 2004). However, there has been little research on political engagement differences by age during adolescence.

Meanwhile, numerous studies have found that political engagement differs in a variety of other demographic categories. For example, highly educated whites (e.g., Fernandez-Ballesteros, Diez-Nicolas, Caprara, Barbaranelli, \& Bandura, 2002; Gaby, 2017) and males (Bowler \& Donovan, 2002) tend to be more politically engaged. Whereas there seem to be persistent political engagement gaps by race (Gaby, 2017), it is unclear whether or not there is still a gender gap (Lee, 2006; McCluskey, Deshpande, Shah, \& McLeod, 2004). Certain contextual factors, such as attending schools that value women's political participation, may affect gender differences in political engagement (Barber \& TorneyPurta, 2009). More research on these demographic differences could strengthen educators' understanding of how to best support all students' political engagement. By exploring such differences as well as the ways in which political interest and efficacy are related to adolescents' expected future political participation, this study makes a valuable contribution to the literature on youth political engagement. 


\section{Research Questions and Hypotheses}

Two main questions guide this paper: First, to what extent and in what ways are political efficacy and political interest related to adolescents' expected future political participation? Based on the theories and research discussed above, we hypothesize that political interest and political efficacy play similarly positive impacts on young people's plans to participate in political activities. Our analyses will allow us to estimate the relative contribution of political interest and efficacy on expected future political participation. Second, we ask in what ways adolescents' political efficacy, interest, and expected future political participation vary by age and other demographic characteristics? As prior research suggests, we expect that males, whites, older students, and those from higher SES backgrounds will have greater political engagement.

\section{Method}

\section{Participants}

Data include survey responses from a sample of 422 adolescents from a state in the midwestern United States. The first author collected these data as part of a larger study of youth political engagement and civic education during a presidential election season. Participants resided in a closely contested "swing state" — where voters have greater influence over the outcome (due to the Electoral College system) and which are more focal to candidates' campaigns (Shear \& Cooper, 2012). These students were enrolled in grades 10 through 12 in four high schools located in three communities, each with different political identities. These schools were selected due to these political identities. One community was heavily Democratic, another was heavily Republican, and the third was split. Students in 
these three communities had political views that largely reflected these trends, though participants favored the Democratic presidential ticket in greater numbers than voters in their respective areas. ${ }^{1}$ Each community around the study sites was the host of at least two major (presidential or vice presidential) candidate visits, some of which were attended by participants and their peers.

Overall, $51 \%$ of the sample was female, and about one quarter was nonwhite. These nonwhite students were diverse, including students who identified as Latinx (7\%), AfricanAmerican (4\%), Asian or Pacific Islander (4\%), Native American (0.5\%), biracial/multiracial (7\%), and other (2\%). Also, about $2 \%$ of students declined to state their race or ethnicity. Participants' average age was 16.7 , and slightly more than half reported that their mothers were college graduates. Approximately 58\% of the sample reported having more than 50 books at home, and about $23 \%$ had fewer than 20 books at home (a proxy for socioeconomic status). Whereas a small number of participants (7\%) reported that their parents or guardians were involved in political activities or groups, more students indicated parental involvement in volunteer activities (23\%) and religious groups (20\%).

\section{Data Collection}

The first author and two graduate-student assistants collected survey data during the fall 2012 semester at high schools in three different communities during class time. Teachers and school administrators gave permission for recruiting students. Before

\footnotetext{
${ }^{1}$ About $57 \%$ of the sample indicated that they preferred Obama, and 33\% preferred Romney. Approximately $5 \%$ were undecided, and the remainder preferred other candidates.
} 
surveys were administered, students in grades 10 through 12 and their parents were informed about the study and asked to sign consent forms that described the rights of research participants. Participation in the study was voluntary, and there were no individual incentives for participation. Researchers administered online surveys in school computer labs by asking participants to visit a web site containing a link to the survey. Completing surveys required students to answer every question, but a small number of students (fewer than 10) did not complete the entire set of questions. (Some potentially sensitive demographic questions gave students the option to "decline to state.") For those who did complete the survey, most did so in 10 to 15 minutes, but a few students took more time. For all analyses, we used only cases in which youth completed the whole survey, including demographic questions.

\section{Measures}

To address our research questions, the survey items measured aspects of adolescents' political engagement, including those described in the literature review above (see the appendix for scales and item wordings). To gauge participants' expected future political participation (EFPP), we asked, using a six-item Likert scale, five questions about how likely participants were to do certain activities after completing high school, such as volunteer for a political party or candidate or talk to others about why they should vote for or against one of the parties or candidates in an election. These measures were drawn from a prior measurement study on civic engagement items (Flanagan, Syvertsen, \& Stout, 2007). As study design did not allow for measures of actual future political behavior, these questions provided a proxy. Prior research indicates that behavioral intentions are related 
to actual behaviors (Webb \& Sheeran, 2006), and other scholars have noted (e.g., Kirshner, 2009; Watts \& Flanagan, 2007) that measuring expected future political participation may be more developmentally appropriate than measuring actual participation.

For political interest, we adapted items from prior studies of the expectancy-value model (Wigfield \& Eccles, 2000), adjusting the original items so that they related to political issues. We used items from the American National Election Study and the first author's measurement study to measure internal political efficacy and external political efficacy (Craig, Niemi, \& Silver, 1990; Levy, 2008). In addition, to enable us to examine relationships between participants' backgrounds and their political engagement, we asked them to share their gender identity, grade level, ethnicity, and home education resources (operationalized as parents' level of education, and the approximate number of books they had at home).

\section{Data Analysis}

To identify political engagement scales, we conducted factor analysis with all relevant items (20 items total from the a priori scales of political interest, internal and external political efficacy, and EFPP). The scree plot clearly showed elbows at 2 and 5, suggesting one- or four-factor solutions would best reflect the data and thus providing support for our hypothesized four factors (Costello \& Osborne, 2005). Following Tabachnick and Fidell (2007), we first used Oblimin rotation, an oblique rotation, as it is reasonable to expect these political factors to correlate (Varimax later produced a very similar solution). As factors correlated at $r=.24$ to .49 , oblique rotation was warranted (Tabachnick \& Fidell, 2007). All items loaded on the expected scale above an absolute value 
of .62 (all but two above .70) and below .25 on all other scales with one exception. An item that asked participants to indicate the future likelihood that they would "vote on a regular basis" loaded highly on both expected future political participation (the intended factor) and political interest. However, as this item was theoretically core to future political participation (i.e., voting is the clearest indicator of political participation), we included it in the theorized construct.

Results of principal component analysis indicated that the items in our survey captured the key underlying constructs in our theoretical model, including youth political interest, political efficacy, and expected future political participation. To create our scales, we added the values of the relevant items and divided the total by the number of items. All scales were highly reliable, with Cronbach's alphas around .9 (see the appendix). In addition, we summed variables related to home education environment (mothers' education, fathers' education, number of books at home) to create a single index to include in our analyses.

We examined distributions and bivariate correlations among political engagement scales and demographic variables, and we conducted $t$-tests and analyses of variance to identify differences across grade level, race, gender, and home education environment. We further examined grade-level differences to identify patterns of engagement across grades. We also examined political engagement variables across intersectional groupings among our dichotomous variables of race and gender, because identities are experienced simultaneously and may influence each other (Cole, 2009). For example, an African American female may experience political efficacy differently from a white female. 
Finally, we explored an expectancy-value model of political engagement by conducting regression analyses exploring the extent to which particular variables related to students' expected future political participation. In order to investigate possible expectancy-value multiplicative effects (as have been found in science motivation research; Nagengast et al., 2011), we created multiple interaction terms and included each in the regression model one at a time. Among our interaction terms were those that included two different political engagement scales (e.g., political interest by external political efficacy) and those that included political engagement scales and demographic variables (e.g., political interest by grade level). In order to mitigate potential multicollinearity, we meancentered continuous variables before creating interaction terms (Robinson \& Schumacker, 2009). With each of our final regression models, we assessed multicollinearity by examining the variance inflation factors.

\section{Results}

\section{Political Engagement Differences by Age and Other Demographic Variables}

The political engagement variables were all positively correlated. The highest bivariate correlations among these scales were between EFPP and political interest ( $r=$ $.64)$ and between political interest and internal political efficacy $(r=.64)$. All others ranged from .36 to .51 . Home education resources and grade level were also positively related to all four of the political engagement scales with correlation coefficients in the .18 to .27 range.

Differences in political engagement across categorical variables appear in Table 1. Results of $t$-tests indicated that male students in our sample had, on average, higher IPE 
than female students $(t(419)=2.5, p<.05)$ but that there were no statistically significant differences between males and females in EPE or political interest (see Table 1). Although students in the sample had higher political interest $(t(420)=2.1 ; p<.05)$ and internal political efficacy $(t(420)=3.2, p<.01)$ than nonwhite students, we found no significant differences in the two groups' EPE or EFPP. Students whose parents were college graduates had higher levels on all political engagement variables than those whose parents did not graduate from college.

Table 1. Demographic Differences on Political Engagement Scales $(N=422) f$

\begin{tabular}{|l|l|l|l|l|}
\hline Category & $\begin{array}{c}\text { Expected Future } \\
\text { Pol. Participation }\end{array}$ & $\begin{array}{c}\text { Pol. } \\
\text { Interest }\end{array}$ & $\begin{array}{c}\text { Internal Pol. } \\
\text { Efficacy }\end{array}$ & $\begin{array}{c}\text { External } \\
\text { Pol. } \\
\text { Efficacy }\end{array}$ \\
\hline Grade Level (ANOVAs)+ & $3.17^{* *}$ & $3.49^{* * *}$ & $3.21^{* * *}$ & $2.91^{* * *}$ \\
\hline Tenth (n=69) & $3.16^{* * *}$ & $3.81^{* *}$ & $3.47^{*}$ & $3.16^{*}$ \\
\hline Eleventh (n=107) & 3.76 & 4.24 & 3.81 \\
\hline Twelfth (n=245) & 3.61 & 3.99 & $3.50^{*}$ & 3.41 \\
\hline Gender (t-tests) & 3.42 & 3.76 & 3.25 \\
\hline Female (n=215) & 3.00 & 3.26 \\
\hline Male (n=206) & 3.53 & $3.80^{*}$ & $3.34^{* * *}$ & 3.35 \\
\hline Minority (T-tests) & 4.08 & 3.72 & 3.50 \\
\hline Minority (n=107) & 3.76 & $3.13^{* *}$ \\
\hline White (n=315) & 4.19 & 4.19 \\
\hline Mother's Education (T-tests) & $3.25^{* * *}$ & $3.79^{* *}$ & $3.79^{* *}$ \\
\hline College Graduate (n=222) & 3.72 & $3.45^{* *}$ \\
\hline Not College Graduate (n=199) & $3.87^{*}$ & $3.50^{* *}$ & $3.20^{*}$ \\
\hline Father's Education (T-tests) &
\end{tabular}

$* * * p<.001 ; * * p<.01 ; * p<.05 ; \sim p<.1$

+ Significance levels indicate differences from $12^{\text {th }}$ grade students, based on Scheffe post-hoc tests following analyses of variance.

$\uparrow$ Total number of respondents was $\mathrm{N}=422$; however, certain questions were optional so $\mathrm{n}$ values for each test vary from $\mathrm{n}=405-422$. For nearly every test, $n$ values were 420-422; however, for father's education, $n$ values were 404-405. 
Our intersectional variable for race and gender yielded the following four groups:

White male ( $n=151,36 \%)$, white female $(n=163,39 \%)$, nonwhite male $(n=55,13 \%)$, and nonwhite female $(n=52,12 \%)$. Political engagement did not vary for these groups across political interest, EPE, or EFPP. However, we found a significant difference $(F[3,417]=$ $5.99, p<.001$ ) for IPE. This omnibus difference was driven by nonwhite females having, on average, significantly lower IPE than others: 3.13 (versus 3.62 white male, 3.84 white female, 3.54 nonwhite male).

Table 2. Standardized Coefficients (and Standard Errors) of OLS Regression Model Examining the Relationship of Demographic Variables to Political Engagement Attitudes $(N=421)$

\begin{tabular}{|l|c|c|c|c|}
\hline $\begin{array}{l}\text { Independent } \\
\text { Variables }\end{array}$ & $\begin{array}{c}\text { Expected Future } \\
\text { Pol. Participation }\end{array}$ & $\begin{array}{c}\text { Political } \\
\text { Interest }\end{array}$ & $\begin{array}{c}\text { Internal Political } \\
\text { Efficacy }\end{array}$ & $\begin{array}{c}\text { External Political } \\
\text { Efficacy }\end{array}$ \\
\hline Grade 12 & $.16(.13)^{* *}$ & $.16(.11)^{* *}$ & $.14(10)^{* *}$ & $.14(.11)^{* *}$ \\
\hline Minority & $.07(.15)$ & $-.01(.13)$ & $-.09(.12) \sim$ & $.02(.12)$ \\
\hline Female & $.03(.13)$ & $-.10(.11)^{*}$ & $-.19(.10)^{* * *}$ & $.03(.10)$ \\
\hline Home Ed. Res. & $.18(.02)^{* *}$ & $.10(.02)^{*}$ & $.11(.02)^{*}$ & $.20(.02)^{* * *}$ \\
\hline Constant & $1.37(.29)^{* * *}$ & $-1.69(.25)^{* * *}$ & $-.75(.21)^{* * *}$ & $-1.26(.23)^{* * *}$ \\
\hline $\mathrm{R}^{2}$ & $.12(1.30)^{* *}$ & $.15(1.10)^{*}$ & $.12(1.01)^{* * *}$ & $.10(1.04)^{* *}$ \\
\hline$* * * p<.001 ; * * p<.01 ; * p<.05 ; \sim p<.1$ & & &
\end{tabular}

Finally, participants' grade levels were related to their political engagement. Results of analyses of variance, including a Scheffe post-hoc test, indicated that 12 th graders (who had reached or were approaching the legal voting age of 18) had higher political interest, expected future political participation, and internal and external political efficacy than 10th or 11th grade students (see Figure 1), and there were no significant differences between $10^{\text {th }}$ and $11^{\text {th }}$ graders on these scales. Because of this, we created a dichotomous variable 
that indicated $12^{\text {th }}$ grade and used it for remaining analyses. Results of OLS regression analyses also indicated that being in $12^{\text {th }}$ grade was closely related to higher political engagement. As Table 2 shows, students in grade 12 had higher expected future political participation, political interest, and internal and external political efficacy than students in $10^{\text {th }}$ and $11^{\text {th }}$ grades, controlling for minority status, gender, and home education resources $(p<.01)$

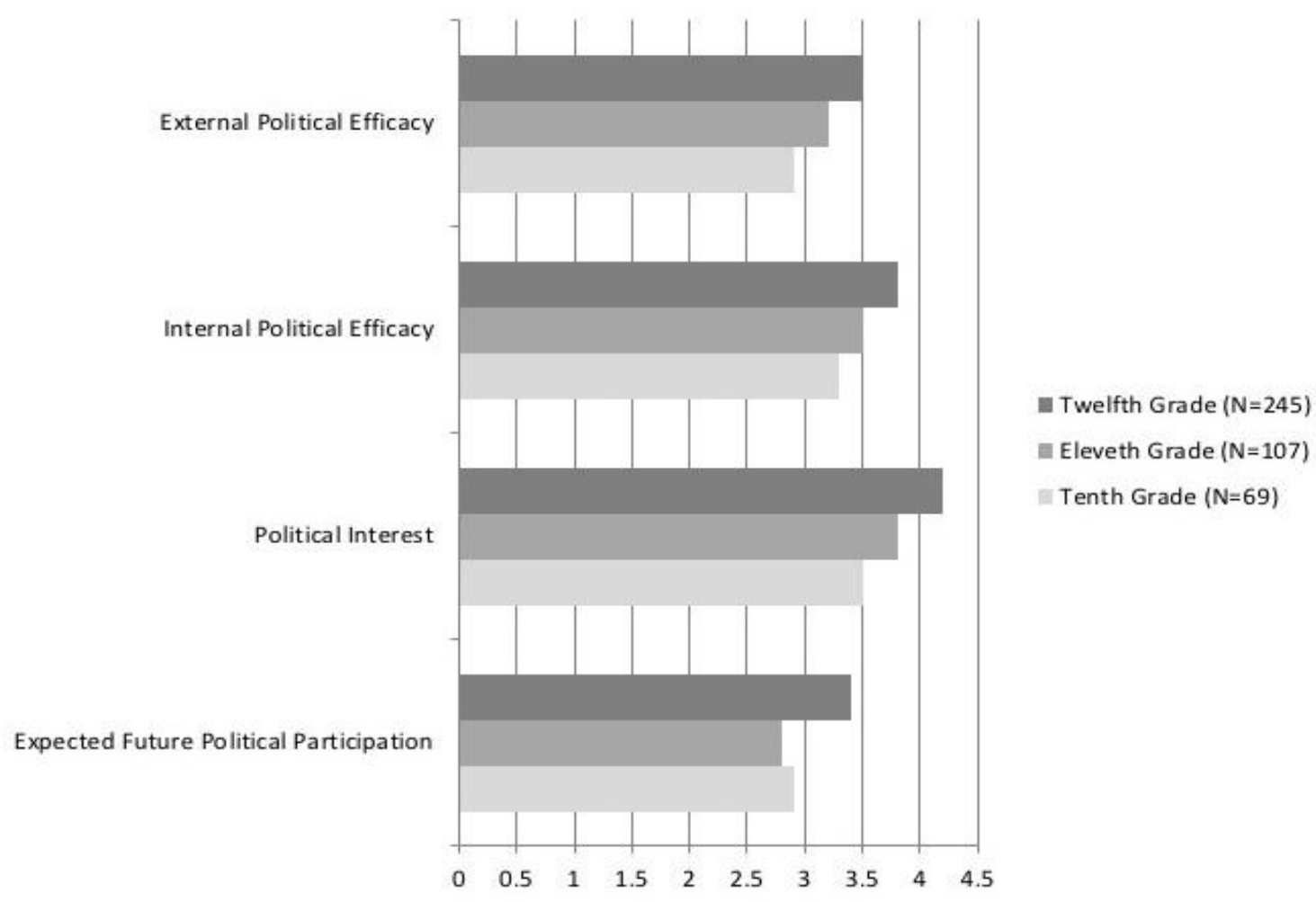

Figure 1. Grade level differences on political engagement scales.

\section{Support for an Expectancy-Value Model of Youth Political Engagement}

Results of regression analyses indicate that political interest and political efficacy are closely related to adolescents' expected future political participation, controlling for a 
variety of background characteristics (see Table 3, Model 1). For every one standard deviation change in students' IPE, their EFPP was .13 standard deviations higher, controlling for grade level, minority status, gender, and home education environment ( $p<$ .001). Likewise, for every standard deviation change in their EPE, participants' EFPP was about 16 standard deviations higher, controlling for background characteristics $(p<.001)$. Our findings indicate an even stronger relationship between political interest and EFPP. For every standard deviation change in participants' political interest, their expected future political participation was more than half of a standard deviation higher, controlling for background characteristics $(p<.001)$. The standardized coefficient for political interest was more than three times larger than the coefficients for IPE and EPE.

Table 3. Standardized Coefficients (and Standard Errors) of OLS Regression Model Examining Students' Expected Future Political Participation $(N=419)$

\begin{tabular}{|l|l|l|}
\hline Variables/Scales & Model 1 & Model 2 \\
\hline Demographics & $.03(.09)$ & $.04(.09)$ \\
\hline Grade 12 & $.07(.10)^{*}$ & $.08(.10)^{*}$ \\
\hline Minority & $.08(.09)^{*}$ & $.08(.09)^{*}$ \\
\hline Female & $.08(.01)^{*}$ & $.08(.01)^{\sim}$ \\
\hline Home Ed. Resources & $.51(.05)^{* * *}$ & $.53(.05)^{* * *}$ \\
\hline Political Engagement & $.13(.06)^{* *}$ & $.13(.06)^{* * *}$ \\
\hline Political Interest & $.16(.05)^{* * *}$ & $.16(.03)^{* * *}$ \\
\hline Internal PE & - & $.12(.03)^{* * *}$ \\
\hline External PE & & $.55(.87)^{* * *}$ \\
\hline Interaction & \multicolumn{3}{|l}{} \\
\hline Interest X Internal PE & $2.98(.17)^{* * *}$ & $2.88(.17)^{* * *}$ \\
\hline \multicolumn{2}{|l|}{}
\end{tabular}

${ }^{* * * *} p<.001 ; * * p<.01 ; * p<.05 ; \sim p<.1$ 
In addition, three demographic variables had small but significant positive relationships with expected political participation. Participants in this study had significantly higher expected future political participation if they were minorities $(p<.01)$, female $(p<.05)$, or from families with more home education resources $(p<.05)$, controlling for political interest and efficacy.

By adding interaction terms as independent variables to our regression analysis, we found that one was significant: political interest by IPE $(p<.001$; see Figure 2 and Table 3 , Model 2). This indicates that the combination of both high political interest and high internal political efficacy relates to higher expected future political participation than would be expected by these individual variables. When we removed this interaction term from the equation and added the other interaction variables one at a time, no other interaction terms were significant.

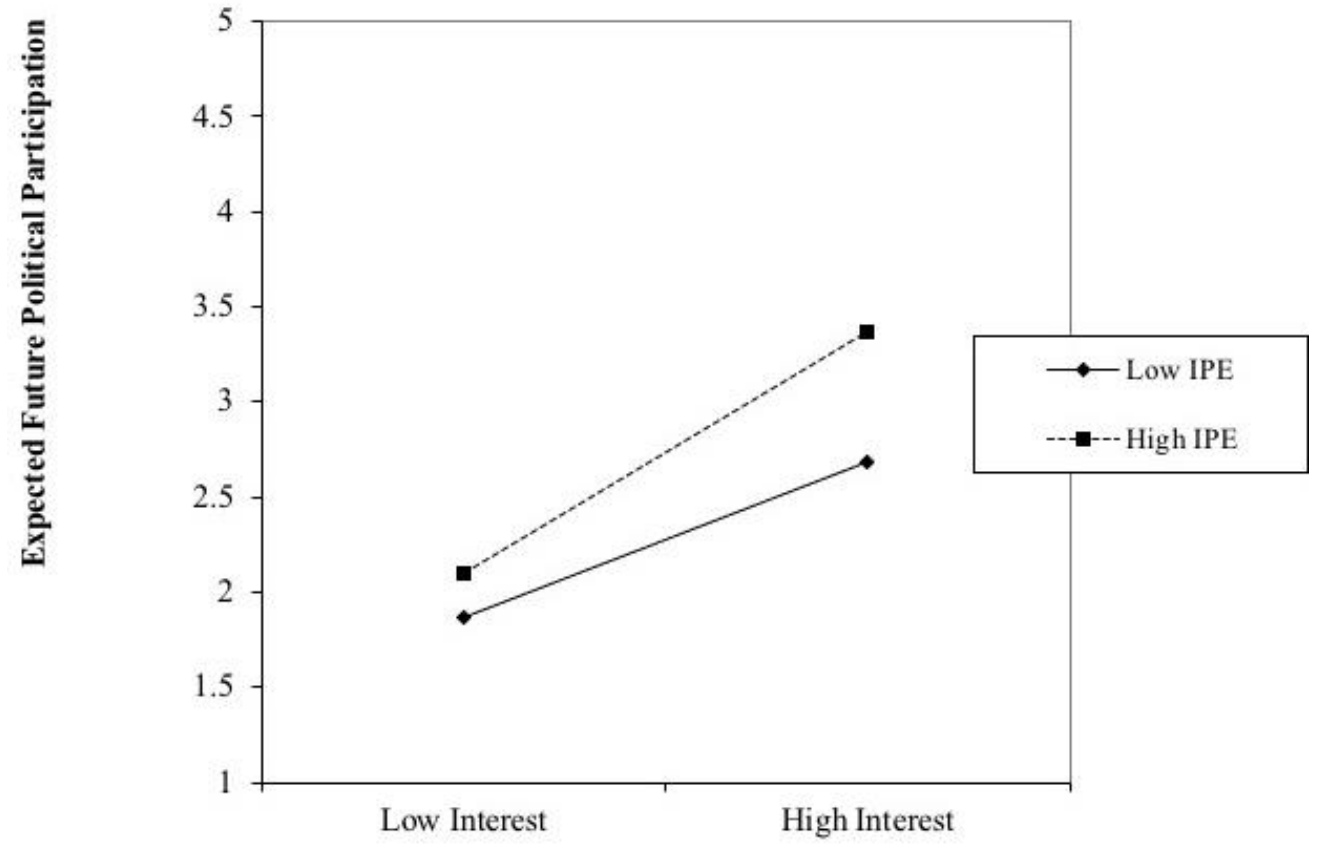

Figure 2. Effect of political interest $x$ internal political efficacy (IPE) interaction on expected future political participation. 
The variables in both models explained about half of the variance in expected future political participation (Model 1: $\mathrm{R}^{2}=.54, p<.001$; Model 2: $\mathrm{R}^{2}=.55, p<.001$ ). In our examination of multicollinearity for these regression models, variance inflation factors were within acceptable ranges (all below 2.0).

\section{Discussion}

This study presents evidence regarding several important issues related to fostering political engagement among youth. First, we found that the expectancy-value model is a useful way to conceptualize motivation to participate in political activities. Our analysis suggests that political interest may be substantially more powerful in predicting future political involvement than political efficacies, a finding with important implications for research and practice. In addition, we found a multiplicative relationship between IPE and political interest. Finally, we identified differences on several political engagement scales among youth with different background characteristics. Below we consider the implications of these findings for both practitioners and scholars.

First, as we just noted, the expectancy-value model can be valuable for describing adolescents' motivation for political participation (see Figure 3) —and it may also be a helpful framework for exploring the nuances of political engagement. Whereas numerous prior studies have found the expectancy-value model useful for explaining young people's motivation in various academic subjects and other domains (Eccles, 2005; Wigfield \& Eccles, 2000), very little previous work explores this model's utility in describing motivation for political participation. Substantial research in political science documents the influence of education levels, race, and other demographic variables on political 
participation, but few prior studies have focused primarily on psychological characteristics while controlling for these background variables. Future studies could build upon the present work by investigating how other aspects of the expectancy-value model, such as perceived utility or cost, could affect individuals' likelihood of political participation.

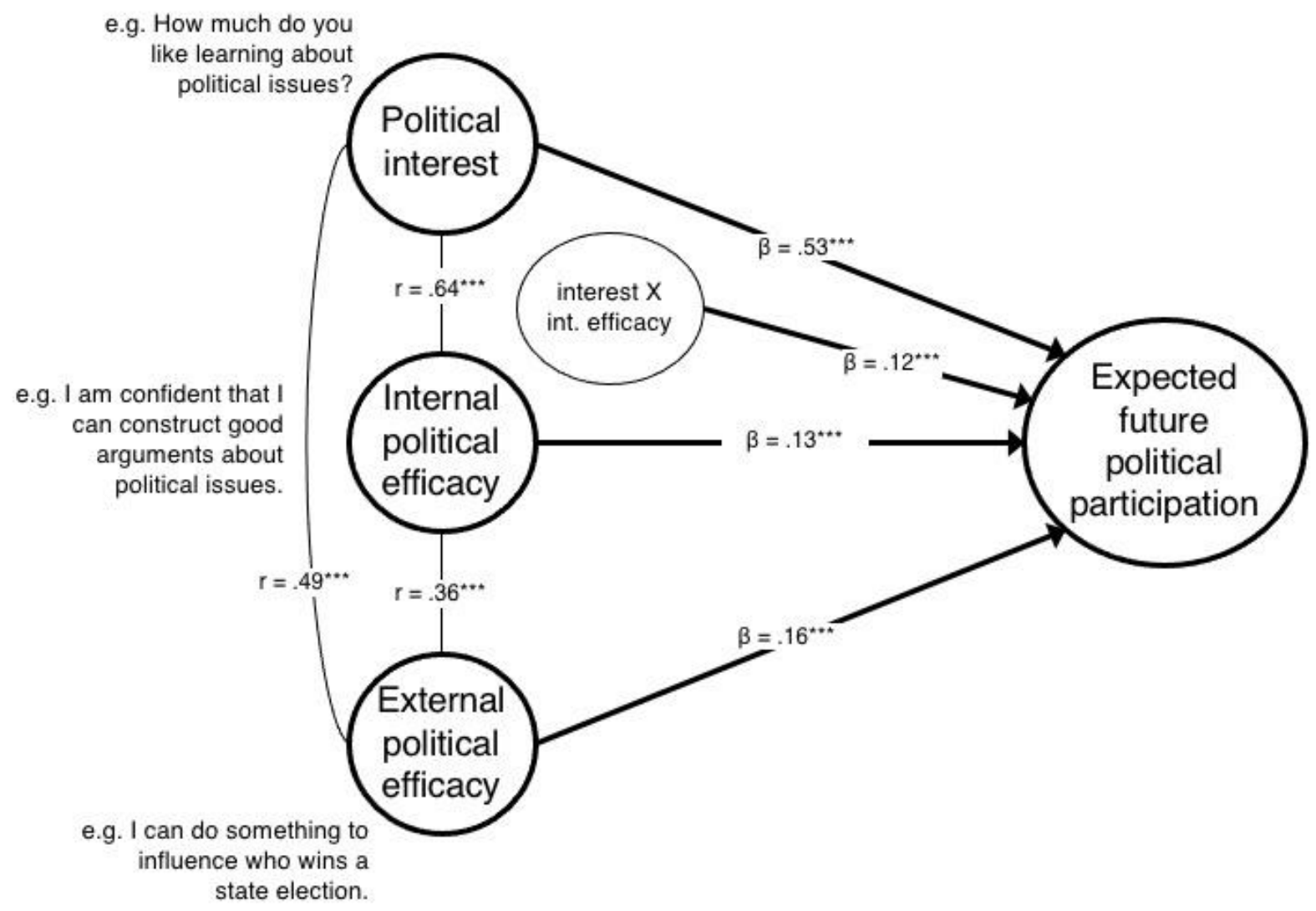

Regression model controls for minority status, sex, grade level, and home education resources

Figure 3. Major findings supporting an expectancy-value model of political engagement (Regression model controls for minority status, sex, grade level, and home education resources).

This study's findings suggest that if educators support students' development of political interest and efficacy, regardless of students' demographic characteristics, they can help to strengthen students' likelihood of becoming active and involved in democratic 
processes. Several studies have identified specific methods that teachers can use to enhance political efficacy, such as legislative simulations (Dressner, 1990; Levy, BabbGuerra, Owczarek, \& Batt, 2019) and discussing salient political issues (Lee, 2006; Levy, 2018; Morrell, 2005; Wells \& Dudash, 2007), but there has been much less research on how educators can foster political interest. Given this study's findings that political interest is more closely related to expected future political participation than political efficacy (see Table 3 and Figure 3), it is important for researchers to identify and examine educational methods for enhancing political interest. In addition, it would be worthwhile for studies to examine the relative impacts of political efficacy and political interest on political participation among a larger, more representative sample.

Our interaction finding further highlights the importance of political interest in fostering political participation. We found that IPE and political interest are mutually supportive, thus providing evidence for an "expectancy X value" model of political motivation. This finding, also echoed in other recent research (Liem \& Chua, 2013), suggests that when young people are both interested in political issues and confident in their political knowledge, they are even more likely to participate in political activities than if either interest or IPE are elevated. Further investigation would help to clarify the precise mechanisms underlying this multiplicative relationship. Nonetheless, educators should explore ways to support both students' IPE and their political interest as a means of enhancing their likelihood of participating in political activities.

Secondly, our findings indicate that educators should consider that age, gender, and race may be a factor in certain aspects of adolescents' political engagement. The 12th graders in our sample had greater political interest, IPE, EPE, and expected future political 
participation than 10th and 11th graders. This suggests that as young people approach or reach the legal voting age, they may feel increasingly engaged in the political sphere. It is possible that as students reach their final year of high school they are more likely to see the relevance of their potential involvement in the political process. This could mean that the ideal time for student motivation in government or related coursework is later during their high school careers. Given that our data are cross-sectional, future research should longitudinally examine political engagement changes among a larger sample of adolescents. It would also be valuable to examine the extent to which these variables could either moderate or influence dimensions of adolescents' political engagement.

Also, in our intersectional analyses, we found that women of color, on average, have lower IPE than white women, white men, and men of color. This indicates that the experience of being in a nondominant racial or ethnic group and the experience of being female may combine in ways that are particularly disadvantageous for developing confidence in one's own political knowledge. Researchers have found that for self-efficacy in math and science, the negative effects of race and gender are cumulative (Charleston, Adserias, Lang, \& Jackson, 2014), and this may also be the case in civic and political domains. Individuals from these backgrounds may be subject to stereotyping, discrimination, and/or limited opportunities (Settles, 2006), so it is important for educators to be attentive to their needs. In future studies, researchers should conduct intersectional analyses in order to better understand the experiences of such groups.

Despite these useful implications, it is important to note the present study's limitations based on the type and breadth of the data. Because participants were in high school, data assessed students' expected future political participation rather than their 
actual participation. To examine the latter and its relationship to political attitudes, future research could be similar to this study but instead include multiple waves or an older population and use slightly different measures (e.g., survey items actual participation, data about online political activities) for the dependent variable scale. Also, the current study is limited by its participants, who were all high school students in a competitive swing state in the midwestern United States. And although we recruited participants that varied by grade level, socioeconomic background, ethnicity, gender, and community type (based on political perspectives), our sample was not necessarily representative of the broader population of adolescents, but this study's sample provides unique insights into a population that may be especially influential in U.S. presidential elections. Indeed, a sample from a different locale and with different demographic characteristics may yield different results; however, given that our findings are reflective of previous work in motivation psychology, we expect that future research with a different or broader population would reach similar conclusions about the utility of the expectancy-value model as a framework on adolescents' motivation to participate in political activities.

\section{Conclusion}

Over the past several decades, the number of democratic nations has increased dramatically, and although the individual rights and freedoms in these countries vary, a growing number of individuals have gained the opportunity to have their voices heard by their governments. Often these voices remain silent, leaving many people poorly represented, so it is important to explore the psychological dimensions that are related to motivating greater political participation. 
This paper's findings suggest that the expectancy-value model can help to explain motivation for political participation, with political interest having the strongest relationship to expected participation. Having higher political interest and political efficacy make individuals more likely to participate in political activities, and certain elements of these two attitudes are mutually supportive. Furthermore, adolescents' political engagement appears to increase as they approach the legal voting age. Researchers should continue to study the ways and extent to which the expectancy-value model can explain different aspects of political participation and the extent to which students' political engagement develops over time. In the meantime, educators interested in fostering adolescents' political involvement should explore and enact strategies for supporting political efficacy and interest among their students. 


\section{References}

Almond, G. \& Verba, S. (1963). The civic culture. Princeton, NJ: Princeton University.

Atkinson, J. W. (1964). An introduction to motivation. Princeton, NJ: Van Nostrand.

Balch, G. (1974). Multiple indicators in survey research: The concept "sense of efficacy." Political Methodology, 1, 1-49.

Barber, C., \& Torney-Purta, J. (2009). Gender differences in political efficacy and attitudes to womens' rights influenced by national and school contexts: Analysis for the IEA civic education study. In D. P. Baker \& A. W. Wiseman (Eds.), Gender equality and education from international and comparative perspectives (pp. 357-394). Bingley, United Kingdom: JAI Press.

Bartels, L. M. (2008). Unequal democracy: The political economy of the new gilded age. New York, NY: Russell Sage.

Beaumont, E. (2010). Political agency and empowerment: Pathways for developing a sense of political efficacy in young adults. In L. Sherrod, J. Torney-Purta, \& C. Flanagan (Eds.), Handbook of research on civic engagement in youth (pp. 525-558). Hoboken, NJ: Wiley. https://doi.org/10.1002/9780470767603

Becker, R. (2005). Political efficacy and voter turnout in East and West Germany. Swiss Political Science Review, 11(1), 57-86. https://doi.org/10.1080/ 0964400042000248223

Bowler, S. \& Donovan, T. (2002). Democracy, institutions, and attitudes about citizen influence on government. British Journal of Political Science, 32(2), 371-390. https://doi.org/10.1017/S0007123402000157

Campbell, A., Gurin, G., \& Miller, W. (1954). The voter decides. Evanston, IL: Row, Peterson. 
Chan, W.Y., Ou, S., \& Reynolds, A. J. (2014). Adolescent civic engagement and adult outcomes. Journal of Youth \& Adolescence, 43(11), 1829-1843. https://doi.org/10.1007/s10964-014-0136-5

Charleston, L. J., Adserias, R. P., Lang, N. M., Jackson, J. F. L. (2014). Intersectionality and STEM: The role of race and gender in the academic pursuits of African American women in STEM. Journal of Progressive Policy \& Practice, 2(3), 273-293.

Cole, E. R. (2009). Intersectionality and research in psychology. American Psychologist, 64(3), 170-180.

Costello, A. B., \& Osborne, J. W. (2005). Best practices in exploratory factor analysis: Four recommendations for getting the most from your analysis. Practical assessment, research \& evaluation, 10(7), 1-9.

Craig, S. C., Niemi, R. G., \& Silver, G. E. (1990). Political efficacy and trust: A report on the NES pilot study items. Political Behavior, 12(3), 289-314. https://doi.org/10.1007/ BF00992337

Deci, E. L., Vallerand, R. J., Pelletier, L. G., \& Ryan, R. M. (1991). Motivation and education: The self-determination perspective." Educational Psychologist, 26(3-4), 325-346.

Diemer, M. A. \& Rapa, L. J. (2016). Unraveling the complexity of critical consciousness, political efficacy, and political action among marginalized adolescents. Child Development 87(1), 221-238. https://doi.org/10.1111/cdev.12446

Dressner, M. M. (1990). Changing energy end-use patterns as a means of reducing global warming trends. The Journal of Environmental Education, 21(2), 41-46. https://doi.org/10.1080/00958964.1990.9941930 
Eccles, J. S. (2005). Subjective task value and the Eccles et al. model of achievement-related choices. In A. J. Elliot \& C. S. Dweck (Eds.), Handbook of competence and motivation (pp. 105-121). New York, NY: The Guilford Press.

Eccles, J. S., Adler, T. F., Futterman, r., Goff, S. B., Kaczala, c. M., Meece, J. L., \& Midgeley, C. (1983). Expectancies, values, and academic behaviors. In T. Spence (Ed.), Achievement and achievement motivation (pp. 75-146). San Francisco, CA: W. H. Freeman.

Ehman, L. H. (1972). Political efficacy and the high school social studies curriculum. In B. G. Massialas (Ed.), Political youth, traditional schools. Englewood Cliffs, NJ: PrenticeHall.

Fernandez-Ballesteros, R., Diez-Nicolas, J., Caprara, G., Barbaranelli, C. \& Bandura, A. (2002). Determinants and structural relation of personal efficacy to collective efficacy. Applied Psychology: An International Review, 51(1), 107-125.

Flanagan, C. A., Syvertsen, A. K., \& Stout, M. D. (2007). Civic measurement models: Tapping adolescents' civic engagement. Medford, MA: Center for Research on Civic Learning and Engagement.

Franklin, M. N. (2004). Voter turnout and the dynamics of electoral competition in established democracies since 1945. Cambridge, United Kingdom: Cambridge University Press.

Gaby, S. (2017). The civic engagement gap(s): Youth participation and inequality from 1976 to 2009. Youth \& Society 49(7), 923-946.

Geys, B. (2006). Explaining voter turnout: A review of aggregate level research. Electoral Studies, 25, 637-663. https://doi.org/10.1016/j.electstud.2005.09.002 
Guyton, E. (1988). Critical thinking and political participation: Development and assessment of a causal model. Theory and Research in Social Education, 16(1), 23-49. https://doi.org/10.1080/00933104.1988.10505554

Hahn, C. L. (1998). Becoming political: Comparative perspectives on citizenship education. Albany: State University of New York Press

Hope, E. C., \& Jagers, R. J. (2014). The role of sociopolitical attitudes and civic education in the civic engagement of black youth. Journal of Research on Adolescence, 24(3), 46070. https://doi.org/10.1111/jora.12117

James, W. (1890). Principles of psychology. New York, NY: Henry Holt.

Jennings, M. K., \& Stoker, L. (2004). Social trust and civic engagement across time and generations. Acta Politica, 39, 342-379. https://doi.org/10.1057/ palgrave.ap.5500077

Kelly, D. C. (2009). In preparation for adulthood: Exploring civic participation and social trust among young minorities. Youth \& Society, 40(4), 526-40. https://doi.org/ $10.1177 / 0044118 \times 08327584$

Kirshner, B. (2009). "Power in numbers": Youth organizing as a context for exploring youth civic identity. Journal of Research on Adolescence, 19, 419-440. https://doi.org/ 10.1111/j.1532-7795.2009.00601.x

Krampen, G. (1991). Political participation in an action-theory model of personality: Theory and empirical evidence. Political Psychology, 12(1), 1-24. https://doi.org/10.2307/ 3791343

Lee, K. (2006). Effects of Internet use on college students' political efficacy. Cyberpsychology \& Behavior, 9(4), 415-422. https://doi.org/10.1089/cpb.2006.9.415 
Leighley, J.E., \& Vedlitz, A. (1999). Race, ethnicity, and political participation: Competing models and contrasting explanations. Journal of Politics, 61(4): 1092-114. https://doi.org/10.2307/2647555

Levine, P. (2007). The future of democracy: Developing the next generation of American citizens. Medford, MA: Tufts University Press.

Levinson, M. (2012). No citizen left behind. Cambridge, MA: Harvard University Press.

Levy, B. L. M. (2008). Developing a new measure of political efficacy. Unpublished manuscript, School of Education, University of Michigan, Ann Arbor.

Levy, B. L. M. (2011). Fostering cautious political efficacy through civic advocacy projects: A

mixed methods case study of an innovative high school class. Theory \& Research in Social Education, 39(2), 238-77.

Levy, B. L. M. (2013). An empirical exploration of factors related to adolescents' political efficacy. Educational Psychology, 33(3), 357-390.

Levy, B. L. M. (2018). Youth developing political efficacy through social learning experiences: Becoming active participants in a supportive Model United Nations club. Theory \& Research in Social Education, 46(3), 410-48.

Levy, B. L. M., Babb-Guerra, A., Owczarek, W., \& Batt, L. M. (2019). Can education reduce political polarization?: Fostering open-minded political engagement during the Legislative Semester. Teachers College Record.

Levy, B. L. M., Solomon, B. G. \& Collet-Gildard, L. (2016). Fostering political interest among youth during the 2012 presidential election: Instructional opportunities and challenges in a swing state. Educational Researcher, 45(9), 483-95. 
Liem, G. A. D., \& Chua, B. L. (2013). An expectancy-value perspective of civic education motivation, learning and desirable outcomes. Educational Psychology, 33(3), 283313. https://doi.org/10.1080/01443410.2013.776934

Lupia, A. \& Philpot, T.S. (2005). Views from inside the Net: How websites affect young adults' political interest. Journal of Politics, 67(4): 1122-1142. https://doi.org/ 10.1111/j.1468-2508.2005.00353.x

Mahoney, J. L., Vandell, D. L., Simpkins, S., \& Zarrett, N. (2009). Adolescent out-of-school activities. In R. M. Lerner \& L. Steinberg (Eds.), Handbook of adolescent psychology (3rd ed., pp. 228-269).. New York., NY: Wiley. https://doi.org/10.1002/ 9780470479193.adlpsy002008

Manning, N. \& Edwards, K. (2014). Does civic education for young people increase political participation? A systematic review. Educational Review, 66(1), 22-45. https://doi.org/10.1080/00131911.2013.763767

McAdam, D. (1988). Freedom summer. Oxford, United Kingdom: Oxford University Press.

McCluskey, M., Deshpande, S., Shah, D., \& McLeod, D. (2004). The efficacy gap and political participation: When political influence fails to meet expectations. International Journal of Public Opinion Research, 16(4), 437-455.

Miller, W. E., Miller, A. H., \& Schneider, E. J. (1980). American National Election Studies Data Sourcebook. Cambridge: Harvard.

Mills, K. L., Lalonde, F., Clasen, L. S., Giedd, J. A., \& Blakemore, S. (2014). Developmental changes in the structure of the social brain in late childhood and adolescence. Social Cognitive and Affective Neuroscience, 9(1), 123-131. https://doi.org/10.1093/scan/ nss113 
Morrell, M. E. (2005). Deliberation, democratic decision-making and internal political efficacy. Political Behavior, 27(1), 49-69. https://doi.org/10.007/ s11109-005-3076-7

Muenks, K., Wigfield, A., \& Eccles, J. S. (2018). I can do this! The development and calibration of children's expectations for success and competence beliefs. Developmental Review, 48, 24-39. https://doi.org/10.1016/j.dr.2018.04.001

Nagengast, B., Marsh, H. W., Scalas, L. F., Xu, M. K., Hau, K. T., \& Trautwein, U. (2011). Who took the " $x$ " out of expectancy-value theory? A psychological mystery, a substantivemethodological synergy, and a cross-national generalization. Psychological Science, 22(8), 1058-1066.

Pei, Z., Pan, Y., \& Skitmore, M. (2018). Political efficacy, social network and involvement in public deliberation in rural China." Social Indicators Research, 139(2), 453-471.

Prior, M. (2010). You've either got it or you don't? The Stability of political interest over the life cycle." Journal of Politics, 72(3), 747-766.

Rasmussen, S. H. R. \& Norgaard, A. S. (2018). When and why does education matter? European Journal of Political Research, 57(1), 24-46. https://doi.org/10.1111/14756765.12213

Robinson, C. \& Schumacker, R. E. (2009). Interaction effects: Centering, variance, inflation factor, and interpretation issues. Multiple Linear Regression Viewpoints, 35(1), 6-11.

Robnett, B. (2007). Does collective identity matter?: African-American conventional and unconventional political participation. Irvine, CA: Center for the Study of Democracy. Rotter, J. B. (1954). Social learning and clinical psychology. Englewood Cliffs, NJ: Prentice Hall. 
Schultz, W. (2005). Political efficacy and expected political participation among lower and upper secondary students. A comparative analysis with data from the IEA Civic Education Study. ECPR General Conference. Budapest, Hungary.

Settles, I. H. (2006). Use of an intersectional framework to understand Black women's racial and gender identities. Sex Roles, 54(9), 589-601.

Shaffer, D. R. \& Kipp, K. (2013). Developmental psychology: Childhood \& adolescence. Belmont, CA: Wadsworth.

Shear, M. D. \& Cooper, H. (2012, October 23). With debates over, candidates race to clinch vital states. New York Times. Retrieved from https://www.nytimes.com/2012/10/24

/us/politics/a-tight-focus-on-battleground-states-as-campaigning-time-dwindles.html

Simmons, D. J. (2014). Social connectivity and the youth vote: Comparing youth voter turnout in 1992 \& 2008. Presented at the National Conference on Undergraduate Research, Lexington, KY.

Smetana, J. G., \& Metzger, A. (2005). Family and religious antecedents of civic involvement in middle class African-American late adolescents. Journal of Research on Adolescence, 15(3), 325-352. https://doi.org/10.1111/j.1532-7795.2005.00099.x

Stromback, J. \& Shehata, A. (2010). Media malaise or virtuous circle? Exploring the causal relationships between news media exposure, political news attention and political interest. European Journal of Political Research, 49, 575-597. https://doi.org/ 10.1111/j.1475-6765.2009.01913.x

Tabachnick, B. G., \& Fidell, L. S. (2007). Using multivariate statistics (5th ed.). Upper Saddle River, NJ: Pearson Allyn \& Bacon.

Tolman, E. C. (1932). Purposive behavior in animals and men. New York, NY: Century. 
United States Elections Project. (2016). National general election VEP turnout rates, 1789Present. Retrieved from http://www.electproject.org/national-1789-present.

Watts, R. J., \& Flanagan, C. (2007). Pushing the envelope on youth civic engagement:

Developmental and liberation psychology perspective. Journal of Community Psychology, 35, 779-792. https://doi.org/10.1002/jcop.20178

Webb, T. L., \& Sheeran, P. (2006). Does changing behavioral intentions engender behavior change? A meta-analysis of the experimental evidence. Psychological Bulletin, 132(2), 249-68.

Wells, S. D., \& Dudash, E. A. (2007). Wha'd'ya know? Examining young voters' political information and efficacy in the 2004 election. American Behavioral Scientist, 50(9), 1280-1289.

Wigfield, A., \& Eccles, J. S. (2000). Expectancy-value theory of achievement motivation. Contemporary Educational Psychology, 25, 68-81. https://doi.org/10.1006/ceps.1999.1015

Wigfield, A., \& Eccles, J. S. (2002). Students' motivation during the middle school years. In J. Aronson (Ed.), Improving academic achievement: Impact of psychological factors on education (pp. 159-184). San Diego, CA: Academic Press.

Wigfield, A., Eccles, J., Mac Iver, D., Reuman, D., \& Midgley, C. (1991). Transitions at early adolescence: Changes in children's domain-specific self-perceptions and general self-esteem across the transition to junior high school. Developmental Psychology, 27, 552-565. https://doi.org/10.1037/0012-1649.27.4.552

Wolak, J. (2018). Feelings of political efficacy in the fifty states. Political Behavior 40(3), 763-784. https://doi.org/10.1007/s11109-017-9421-9 
Wu, C.-L. (2003). Psycho-political correlates of political efficacy: The case of the $1994 \mathrm{New}$ Orleans mayoral election. Journal of Black Studies, 33(6), 729-760.

Zukin, C., Keeter, S., Andolina, M., Jenkins, K., \& Delli Karpini, M. X. (2006). A new engagement? Political participation, civic life, and the changing American citizen. Oxford, United Kingdom: Oxford University Press. 


\section{Appendix}

\section{Political Engagement Scales}

Expected Future Political Participation $(\alpha=.88)$

Responses: Not likely at all ... extremely likely (six levels)

When you think about your life after high school, how likely is it that you would do each of the following:

1. Vote on a regular basis

2. Wear a campaign button to support a candidate

3. Volunteer for a political party or candidate

4. Participate in political activities, such as a protest, march, or demonstration

5. Talk to others about why they should vote for or against one of the parties or candidates in an election

\section{Political Interest $(\alpha=.93)$}

1. Generally speaking, how interested are you in political issues or current events? (not at all interested ... extremely interested)

2. Generally speaking, how interested are you in learning about political campaigns (not at all interested ... extremely interested)

3. Compared to most of your other activities, how useful is learning about political issues (not at all useful ... extremely useful)

4. For me, understanding political issues is: (not at all important ... extremely important)

5. How much do you like learning about political issues? (dislike extremely ... like extremely)

\section{Internal Political Efficacy $(\alpha=.89)$}

Responses: Strongly Disagree ... Strongly Agree

1. I feel that I have a pretty good understanding of the important political issues facing our country.

2. I feel that I have a pretty good understanding of the important political issues facing our world.

3. I am confident that I can construct good arguments about political issues.

4. I can write clearly about political issues.

5. I often don't feel sure of myself when talking with other people about politics and government. [reverse coded]

\section{External Political Efficacy $(\alpha=.90)$}

Responses: Strongly Disagree ... Strongly Agree

1. Public officials care what people like me think.

2. If there's a serious local problem, I can do something to get local elected officials to improve the situation. 
3. If there's a serious problem in my state, I can do something to get state elected officials to improve the situation.

4. If there's a serious national problem, I can do something to get federal elected officials to improve the situation.

5. I can do something to influence who wins a local election.

6. I can do something to influence who wins a state election. 